\title{
Low-temperature directed crystallization as a realization of Green Chemistry principles.
}

\author{
L.P.Eksperiandova
}

\author{
Institute for Single Crystals, STC "Institute for Single Crystals", \\ National Academy of Sciences of Ukraine, \\ 60 Nauky Ave., 61001 Kharkiv, Ukraine
}

\section{Received May 13, 2016}

It is proposed a hybrid method for determination of water using low temperature directed crystallization. The length of the opaque upper part of obtained ice ingot depends on total salinity of water and serves as an analytical signal. Simultaneously the presence of dominant anions can be visually determined by configuration of the opaque part. The concentrate of micro-impurities localized after the crystallization in the upper part can be separated from the ice ingot and left to the following analysis. The method is compared favorably with such standard methods as gravimetry and conductometry used for water salinity determination. The reagentless method complies with the principles of Green Chemistry, since its application does not lead to pollution of the environment.

Keywords: low temperature directed crystallization; natural water; total water salinity; anionic macro-composition; microimpurity pre-concentration; Green Chemistry.

Предложен гибридный метод определения минерализации воды с использованием низкотемпературной направленной кристаллизации. Длина непрозрачной части полученного ледяного слитка зависит от общего содержания в воде солей и служит аналитическим сигналом. Одновременно по форме непрозрачной части можно визуально определить присутствие в воде доминирующих анионов. Концентрат микропримесей, локализованный в верхней части ледяного слитка, может быть отделен и оставлен для последующего анализа. Метод не уступает таким стандартным методам, как гравиметрия и кондуктометрия, применяемым для определения минерализации воды. Будучи безреагентным, метод соответствует принципам Зеленой Химии, так как его реализация не приводит к загрязнению окружающей среды.

Низькотемпературна спрямована кристалізація як реалізація принципів Зеленої Хімії. Л.П.Експеріандова.

Запропоновано гібридний метод визначення мінералізації води із використанням низькотемпературної спрямованої кристалізації. Довжина непрозорої частини льодяного зливку, що отримується, залежить від загального вмісту у воді солей та є аналітичним сигналом. Одночасно за формою непрозоро частини можна візуально визначити присутність у воді домінуючих аніонів. Концентрат мікродомішок, що локалізується у верхній частині льодяного зливку, можна відділити і залишити для наступного аналізу. Метод не поступається таким стандартним методам, як гравіметрія і кондуктометрія, які застосовуються для визначення мінералізації води. Будучи безреагентним, метод відповідає принципам Зеленої Хімії, оскільки його реалізація не викликає забруднення довкілля.

\section{Introduction}

It is well-known that analytical chemistry uses combined and hybrid methods. The criterion for such a classification is the presence or absence of the new quality during implementation of analytical procedure.
The combined methods imply separation in time of the stages of specimen preparation and of the analysis itself. The hybrid methods require simultaneous formation of the analytical signals and the specimen preparation process. The classic examples of the 
hybrid methods are chromatography and inversion voltammetry. Crystallization concentration of impurities may also be considered as the hybrid method.

A.B.Blank and his collaborators [1] investigated regularities of the high-temperature $\left(\approx 1000^{\circ} \mathrm{C}\right)$ directed crystallization (HDC) which were applied to concentration of micro-impurities in inorganic compounds before the process of their analysis. In particular, there was examined the mechanism of impurity entry into solid phase. If the ratio of radii of the main and the impurity atoms in the melt does not exceed 10-15\%, there will be realized the substitution mechanism. The mechanism of incorporation will work in the case when the radii of the impurity atoms are such that the latter can occupy the crystal lattice interstices. In the both cases the equilibrium coefficients of the impurity segregation between the solid and liquid phases $\left(k_{0}\right)$ calculated from the state diagram (or estimated at infinitesimal crystallization rate), are nonzero. Later [24] there was investigated the low-temperature directed crystallization (LDC) of water solutions of salts, in particularly, of some functional materials (FM) at temperatures below 0198C. It should be noted that research of the LDC for analytical purposes, mainly devoted to the author's perennial work with the employees. Publications of other authors on the study of peculiarities of the low-temperature crystallization are rare $[5-10]$. As a rule, they are devoted to technical peculiarities of purification of inorganic water objects. Analytical freezing-out of ice from aqueous solutions described only in $[9,10]$, where the crystallization is directed from the walls to the center of a bottle. The liquid enriched by impurities is in the center of the vessel and removing concentrate presents some difficulty.

Since the ions contained in the solution is surrounded by their own hydrate shell, they cannot enter to the crystal lattice of the salt or ice, and the impurities have to "squeeze" between ice crystallites. In this case $k_{0}=0$. Thereat, the characteristic segregation coefficients $\left(k_{L}\right)$ [1] are non-equilibrium, non-zero and depend on the preset crystallization conditions [11]. Such coefficients were estimated experimentally using the Gulliver-Pfann equation [12] modified by Blank [1]. The latter connects the initial impurity concentration $\left(C_{0}\right)$ before the onset of LDC, its concentration in the liquid phase $\left(C_{L}\right)$ during crystallization process, the share $(g)$ of the crystallized ingot and

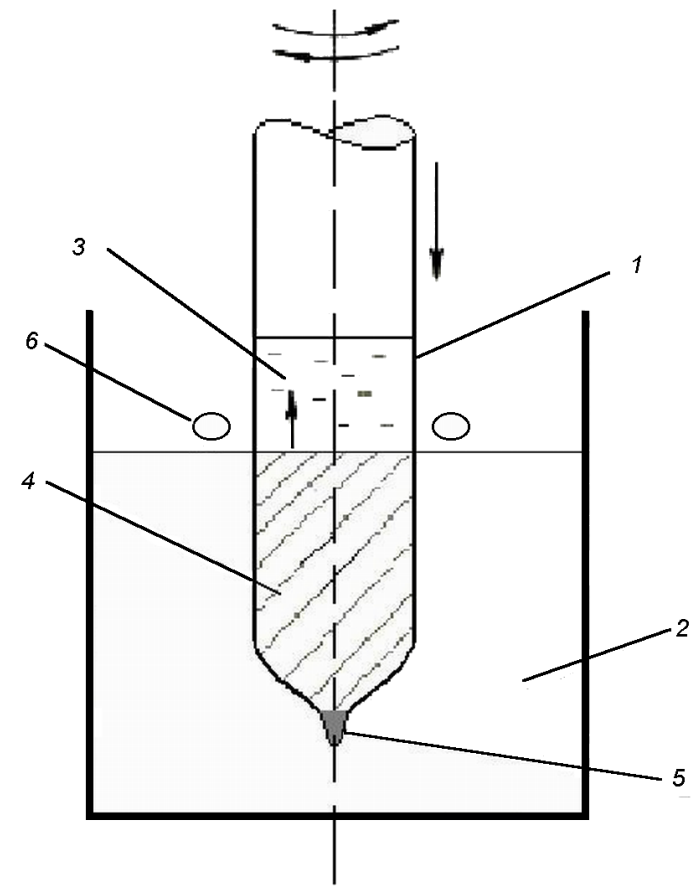

Fig. 1. Scheme of LDC process: 1 - glass container; 2 - antifreeze; 3 - liquid phase of the water to be analyzed; 4 - pure ice; 5 - seed; 6 - heater.

$k_{L}$. For the calculations there were used preliminarily obtained experimental $k_{L}$ values. In $[2,3,13-16]$ the use of LDC for analytical concentration of impurities from water and aqueous solutions is described.

The aim of the present work was to study another possibility of LDC application - as the hybrid method without using reagents for determination of the total salinity of natural water and qualitative estimation of its anionic macro-composition.

\section{Experimental}

Process of LDC was performed from below upwards at $-15^{\circ} \mathrm{C}$ (the temperature sufficient for creation of the required overcooling of the solution before the onset of crystallization) using the model setup [13]. The investigated solutions were agitated by reverse rotation of glass containers with constant (in the case of salinity evaluation) or varying (in the case of impurity pre-concentration) cross-sections. The containers with the investigated solutions slowly descended into the antifreeze cooled using evaporator of a compression-type refrigerator (Fig. 1).

After LDC the impurity concentrate was separated by adding hot water $(0.8 \mathrm{~mL})$ to the upper part of the ice ingot. The resulting mixture consisting of this water and the 
Table $^{\mathrm{a}}$. Details of techniques with preliminary crystallization concentrating impurities from aqueous salt solutions of FM, $P=0.95, n=5-7$

\begin{tabular}{|c|c|c|c|c|c|}
\hline Salt basis & Impurity & $k_{L}$ & $C_{l i m}$, wt. $\%$ & $\mathrm{SR}$ & $\begin{array}{c}\text { Method of } \\
\text { determining }\end{array}$ \\
\hline \multicolumn{6}{|c|}{ Cationic impurities } \\
\hline \multirow[t]{4}{*}{ Csl } & $\mathrm{Cu}(\mathrm{I}, \mathrm{II})$ & $0.09 \pm 0.02$ & $2 \cdot 10^{-6}$ & 60 & \multirow[t]{2}{*}{ SP } \\
\hline & $\mathrm{Fe}(\mathrm{II}, \mathrm{II})$ & $0.025 \pm 0.007$ & $1 \cdot 10^{-6}$ & 90 & \\
\hline & U(VI) & $0.10 \pm 0.01$ & $5 \cdot 10^{-7}$ & 120 & \multirow[t]{2}{*}{ SP } \\
\hline & Th(IV) & $0.08 \pm 0.01$ & $5 \cdot 10^{-7}$ & 120 & \\
\hline $\mathrm{RbNO}_{3}$ & \multirow{2}{*}{$\begin{array}{l}\text { Heavy metals } \\
\text { sum }\end{array}$} & $0.10 \pm 0.01$ & $5 \cdot 10^{-5}$ & 100 & EPD \\
\hline Csl & & $0.04 \pm 0.01$ & $5 \pm 10^{-5}$ & & \\
\hline \multicolumn{6}{|c|}{ Anionic impurities } \\
\hline \multirow[t]{3}{*}{ Csl } & $\mathrm{CO}_{3}{ }^{2-}$ & $0.09 \pm 0.02$ & $4 \cdot 10^{-6}$ & 66 & KM \\
\hline & $\mathrm{SO}_{4}{ }^{2-}$ & $0.10 \pm 0.02$ & $3 \cdot 10^{-6}$ & 100 & $\mathrm{~T}$ \\
\hline & $\mathrm{CrO}_{4}^{2-}$ & $0.07 \pm 0.01$ & $2 \cdot 10^{-6}$ & 70 & SP \\
\hline $\mathrm{NH}_{4} \mathrm{NO}_{3}$ & $\mathrm{SO}_{4}^{2-}$ & $0.08 \pm 0.01$ & $1 \cdot 10^{-5}$ & 50 & $\mathrm{~T}$ \\
\hline \multicolumn{6}{|c|}{ Chemical analogues of salt basic } \\
\hline \multirow[t]{4}{*}{ Csl } & $\mathrm{Li}^{+}$ & $0.077 \pm 0.009$ & $3 \cdot 10^{-6}$ & 70 & \multirow[t]{2}{*}{ EFP } \\
\hline & $\mathrm{Rb}^{+}$ & $0.060 \pm 0.008$ & $3 \cdot 10^{-6}$ & 70 & \\
\hline & $\mathrm{Br}^{-}$ & $0.16 \pm 0.02$ & $5 \cdot 10^{-5}$ & 100 & XRS \\
\hline & $\mathrm{Cl}^{-}$ & $0.06 \pm 0.02$ & $2 \cdot 10^{-6}$ & 100 & $\mathrm{~T}$ \\
\hline \multirow[t]{2}{*}{$\mathrm{KBr}$} & $\mathrm{Li}^{+}$ & $0.38 \pm 0.03$ & $1 \cdot 10^{-5}$ & 20 & \multirow[t]{2}{*}{ EFP } \\
\hline & $\mathrm{Rb}^{+}$ & $0.43 \pm 0.01$ & $1 \cdot 10^{-5}$ & 20 & \\
\hline \multicolumn{6}{|c|}{ Organic impurities } \\
\hline Csl & \begin{tabular}{|c|} 
Organic \\
impurities sum
\end{tabular} & $0.04 \pm 0.01$ & $2 \cdot 10^{-5}$ & 100 & $\mathrm{C}$ or $\mathrm{P}$ \\
\hline
\end{tabular}

a Table data are selectively taken from [17, Chap. 3]. $C_{\text {lim }}$ is limit of detection for the methods with pre-concentration, SR is sensitivity rise (pre-concentration efficiency);

b SP - spectrophotometry; EPD - extraction-photometric determination; KM - kinetic method; $\mathrm{T}$ - turbidimetry; EFP - emission flame photometry; XRS - X-ray spectrometry; C - coulometry; $\mathrm{P}-$ potentiometry.

melted part of the ingot (1-2 $\mathrm{mL}$ ) was used for subsequent analysis.

The length of the opaque part of the ice ingot was measured after LDC by a conventional ruler applied to the exterior surface of the container with the ingot.

\section{Results and discussion}

If the LDC is realized for impurity concentration, the separated concentrate is analyzed by suitable method used for small quantities of water solution, for instance, atomic-absorption or multi-element X-ray fluorescence techniques. In this case the method is the combined one. It should be noted that the LDC is compared favorably with other concentration methods by the possibility of automated control, the absence of reagents (low background level), as well as of chemical transformations and interaction with container material [13, 17].
There was shown that impurity segregation in the process of the LDC gives rise to effective (on 1.5-2 order) group concentration from the aqueous solutions of FM (Table 1). There was also shown that the segregation does not depend on the nature of these impurities (simple and complex anions, cations of alkali, alkaline earth and heavy metal, complex compounds, colloidal or suspended particles, organic compounds). And, as mentioned above, the equilibrium segregation coefficients are equal to zero. At the same time, the characteristic coefficients which define the degree of non-equilibrium capture of the impurities by the solid phase depend on the crystallization rate and, as it turned, on the concentration of the macrocomponent salt dissolved in water. Therefore, at the LDC initial stage the ice ingot has single-crystalline structure and is transparent. When the crystallization front starts moving and rejecting the salt, the 


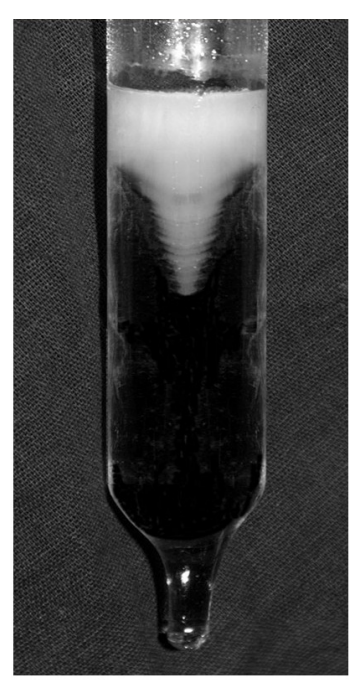

a)

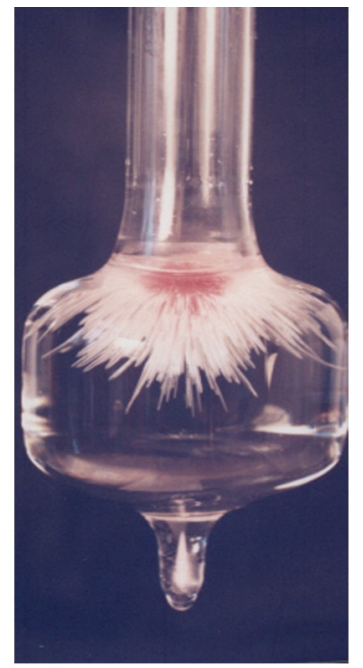

b)
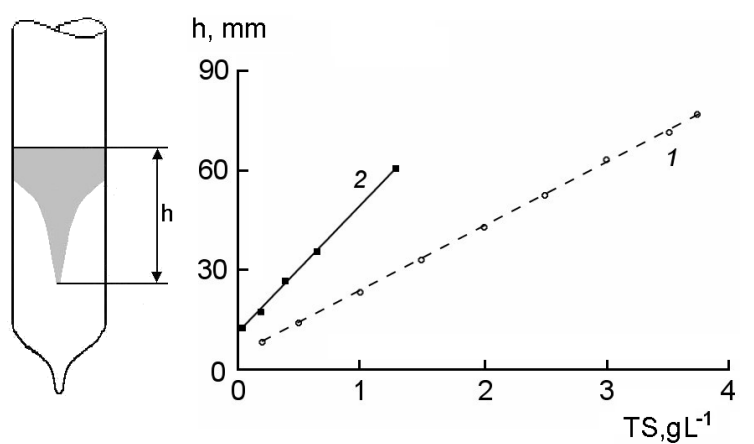

Fig. 3. Length of opaque part of the ingot (h) vs total salinity (TS) of water at the fixed crystallization speed: $1-20 \mathrm{~mm} \mathrm{~h}^{-1}, 2-$ $40 \mathrm{~mm} \mathrm{~h}^{-1}$.

pounds. In addition, it is impossible to analyze the carbonated mineral water. Often, such estimate is realized using the standard gravimetric analysis which consists in a long period of careful evaporation of large amounts of water and lasts for many hours. Table 2 presents the reproducibility of the results of the crystallization determination of total salinity of the artificial water mixtures.

The proposed method has a number of advantages and it is compared favorably with the gravimetric methods. Since at the LDC of water the soluble (dissociated and non-dissociated) and insoluble impurities are segregated between the solid and liquid phases, the salinity values obtained by the proposed method take into account impurities of any nature contained in the analyzed water. Forced carbonation of water does not influence the obtained results, as the gases rejected by the crystallization front enter in atmosphere. The process is realized at the low temperature which excludes chemical transformation of the components, and does not

Table 2. Comparison of results of determining the total salinity of natural waters in Kharkiv region $(n=3-5, P=0.95)$

\begin{tabular}{|c|c|c|c|c|c|c|}
\hline \multirow[t]{2}{*}{ Water sample } & \multicolumn{3}{|c|}{ Salinity, $\mathrm{mg} \cdot \mathrm{L}^{-1}$, found by the method } & \multicolumn{3}{|c|}{ Basic anions, $\mathrm{mg} \cdot \mathrm{L}^{-1}$} \\
\hline & LDC & Conductivity & $\begin{array}{l}\text { Gravimetry, } \\
\text { soda variant }\end{array}$ & $\mathrm{Cl}^{-}$ & $\mathrm{SO}_{4}{ }^{2-}$ & $\mathrm{HCO}_{3}-$ \\
\hline River water & $520 \pm 40$ & - & $480 \pm 25$ & 14 & 87 & 232 \\
\hline Well, $20 \mathrm{~m}$ & $1150 \pm 90$ & - & $1160 \pm 60$ & 421 & 67 & 270 \\
\hline Well, $50 \mathrm{~m}$ & $1040 \pm 80$ & - & $1000 \pm 50$ & 43 & 212 & 555 \\
\hline Deep well, $700 \mathrm{~m}$ & $540 \pm 40$ & - & $510 \pm 30$ & 42 & 85 & 295 \\
\hline $\begin{array}{c}\text { Bottled } \\
\text { carbonated water }\end{array}$ & $830 \pm 65$ & $\begin{array}{l}\text { definition } \\
\text { impossible }\end{array}$ & $860 \pm 45$ & 320 & 25 & 380 \\
\hline Spring & $759 \pm 51$ & $707 \pm 5$ & $698 \pm 31$ & 25 & 234 & 300 \\
\hline Tap water & $767 \pm 75$ & $711 \pm 4$ & $705 \pm 19$ & 20 & 312 & 185 \\
\hline
\end{tabular}



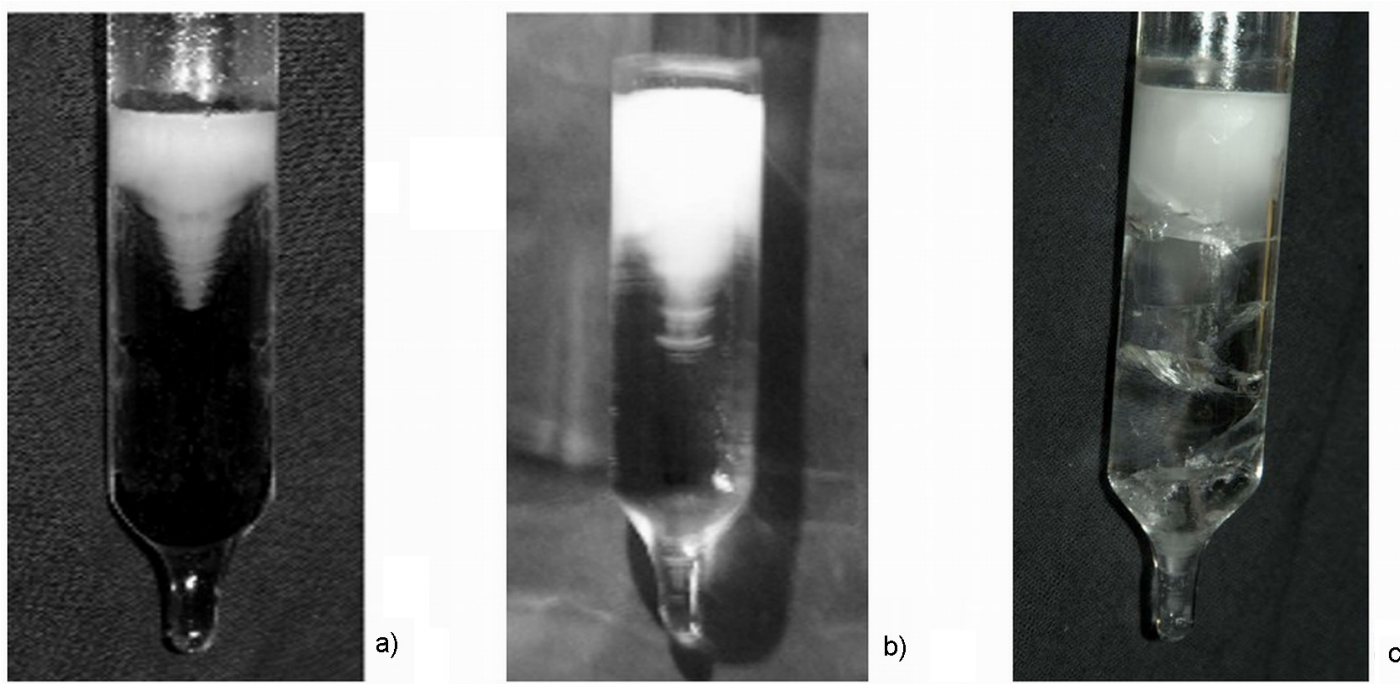

c)

Fig. 4. View of the ice ingot after LDC of water depending on the nature of macro-anion: a) chloride, b) - sulphate, c) - hydrocarbonate $\left(f=20 \mathrm{~mm} \mathrm{~h}^{-1}\right.$, volume $\left.15 \mathrm{~mL}\right)$.

require permanent presence of operators, since the crystallization procedure is automated. The analysis is in progress for approximately $1.5 \mathrm{~h}$ (at $f=40 \mathrm{~mm} \mathrm{~h}^{-1}$ - for waters with high salinity) or 3 hours (at $f=$ $20 \mathrm{~mm} \mathrm{~h}^{-1}$ - for waters with medium salinity), and the amount of water necessary for its implementation is only $15 \mathrm{~mL}$.

Unexpected result was that evaluation of TS can be done in appearance of the ice ingot visually without chemical analysis evaluation of which of the basic natural water anions - chloride, sulfate, hydrocarbonate - predominates in the sample. It turned out that the dominant cations of natural water does not affect the appearance of the ingot. Fig. 4 shows the dependence of appearance of the ingot from the nature of the anion. It can be seen that the opaque part of chloride water is always shaped as a regular overturned cone, the sulphate water has "feathers" at the vertex, the hydrocarbonate water contains fractures and gas bubble inclusions. Different external appearance of the ice ingots obtained from the said solutions is explained proceeding from the temperature dependences of the solubility of the corresponding sodium salts (Fig. 5). The solubility of hydrocarbonates and, especially, of sulphates considerably lowers at temperature reduction. This gives rise to supersaturation at the crystallization front followed by periodic concentration drop (its traces are observed in the ingot as "feathers"). It is known that the solubility of chlorides slightly depends on the temperature and, which is more essential, remains high at the working tem-

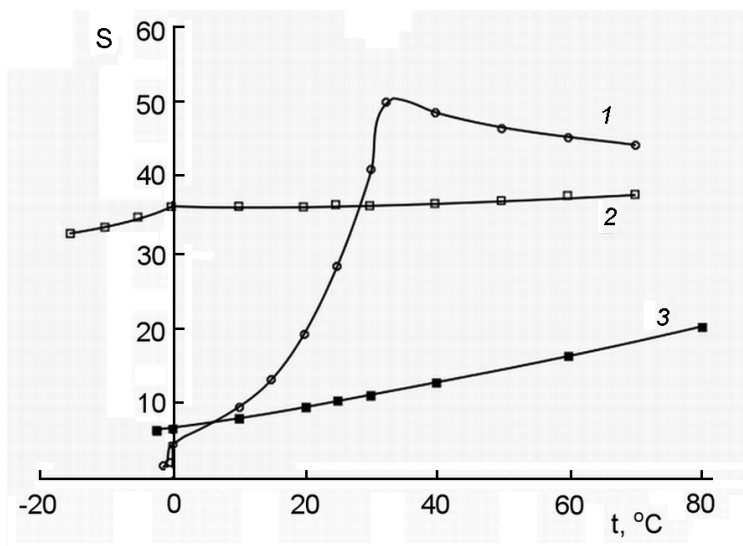

Fig. 5. Comparable trends in solubilities $S$ (g per $100 \mathrm{~g}$ water) of sodium sulfate, chloride and hydrocarbonate: $1-\mathrm{Na}_{2} \mathrm{SO}_{4}, 2-\mathrm{NaCl}$, $3-\mathrm{NaHCO}_{3}$.

perature $\left(-15^{\circ} \mathrm{C}\right)$. Therefore, in the case of chlorides concentration overcooling at the crystallization front hardly occurs, and the shape of the opaque cone remains practically unchanged. This shape is a result of the action of two concurrent processes: centripetal compression at the container rotation and movement of the crystallization front along the normal to its plane. Crystallization of the solution based on hydrocarbonate has own features. Only this ice ingot contains tiniest gas bubbles (Fig. 6). This is evidently caused by the fact that in the process of crystallization a small amount of carbon dioxide formed at hydrocarbonate dissolution in water is captured as a mechanical impurity by the solid phase of ice. Thereat, such gas bubbles become the centres of stresses and subsequent deformation of the ice crystal. The directed crystal- 


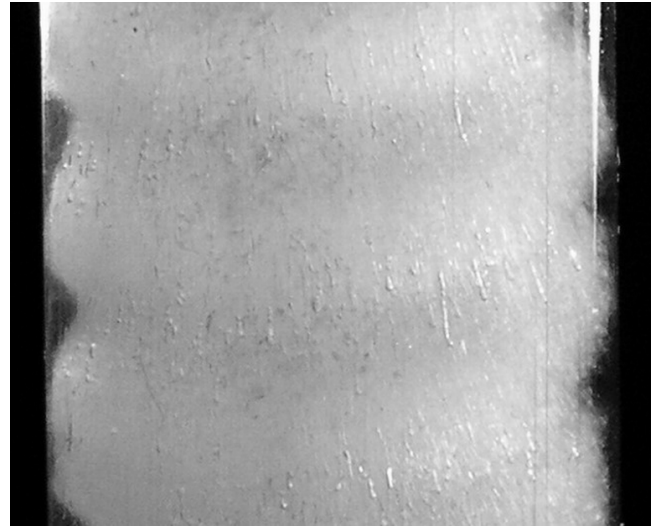

Fig. 6. Enlarged photographic fragment of the ice ingot after LDC $\left(f=20 \mathrm{~mm} \mathrm{~h}^{-1}\right)$ water containing hydrocarbonates (throughout the volume the inclusions of gas bubbles are observed).

lization of this solution gives rise to faults in the single crystal ice ingot.

The described comprehensive qualitative estimation does not require much time. It may be used e.g. for simple and rapid sorting of chloride, sulfate or hydrocarbonate drinking waters $\left(\mathrm{g} \mathrm{L}^{-1}\right)$ : dining $\operatorname{room}(T S<$ $1)$, medical-table $(1<T S<2)$ or therapeutic one $(2<T S<4)$.

Thus, the LDC simultaneously provides reagentless group concentration of microimpurities, determination of total salinity and qualitative analysis of water. In the latter two cases the criterion by which the method of analysis referred to the hybrid is met. The described crystallization method complies with the principles of Green Chemistry, since its realization does not lead to the environment pollution.

\section{Conclusions}

It is shown that LDC method of determination of water salinity is the hybrid one, since an analytical signal is formed in the process of crystallization.

The proposed method is compared favourably with the gravimetric and conductometric methods, as it permits to determine the salinity of water containing soluble, insoluble, dissociated, non-dissociated and termally unstable impurities, thereat, the crystallization procedure is automated.

Simultaneously with TS evaluation, the method makes it possible to visually find out the basic anions (chloride, sulphate or hydrocarbonate) predominating in the samples of natural water, judging from the appearance of the obtained ice ingots.

The considered method is nonchemical and complies with the principles of Green Chemistry, since its application does not lead to pollution of the environment

\section{References}

1. A.B.Blank, Analysis of Pure Substances by Means of Crystallization Preconcentration, Khimiya, Moscow (1986) [in Russian].

2. L.P.Eksperiandova, I.I.Fokina, T.I.Ivkova, A.B.Blank, J. Trace Microprobe Techn., 19, 71 (2001).

3. L.P.Eksperiandova, A.B.Blank, I.I.Fokina et al., Anal. Chim. Acta, 396, 317 (1999).

4. L.P.Eksperiandova, I.B.Shcherbakov, J.Sol. Chem., 35, 1075 (2006).

5. R.Halde, Water Res., 14, 575 (1980).

6. F.van der Ham, M.M.Seckler, G.J.Witkamp, Chem. Eng. Process., 43, 161 (2004).

7. K.Watanabe, Y.Muto, M.Mizoguchi, Cryst. Growth Design., 1, 207 (2001).

8. Y.Wang, L.L.Regel, W.R.Wilcox, Crystal Growth Design., 2, 453 (2002).

9. G.H.Smith, M.P.Tasker, Anal.Chim.Acta. 33, 559 (1965).

10. J.Shapiro, Science, 133, 2063 (1961),

11. L.P.Eksperiandova, A.B.Blank, Zh.Fiz. Khimii, 52, 1837 (1976).

12. W.G.Pfann, Zone Melting, John Willey \& Sons, New York, London, Sydney (1966).

13. L.P.Eksperiandova, Functional Materials, 17, 401 (2010).

14. L.P.Eksperiandova, I.I.Fokina, A.B.Blank, N.N.Grebenyuk, J.Anal.Chem., 57, 194 (2002).

15. A.B.Blank, L.P.Eksperiandova, X-Ray Spectrometry, 27, 147 (1998).

16. J.Injuk, R.van Grieken, A.B.Blank et al., Handbook of Practical X-ray Fluorescence Analysis, Springer Verlag, Berlin, Wien, New York, Tokyo (2006).

17. A.B.Blank, Analytical Chemistry in the Study and Production of Inorganic Functional Materials, Institute for Single Crystals, Kharkov (2005) [in Russian]. 